\title{
On features of deoxidization of CsI melt with zirconium getter
}

\author{
Yu.N.Datsko ${ }^{1}$, T.P.Rebrova ${ }^{1}$, V.L.Cherginets $^{1}$, V.A.Naumenko $^{1}$, \\ A.L.Rebrov ${ }^{1}$, P.V.Mateychenko ${ }^{2}$, I.N.Vjunnik ${ }^{3}$ \\ ${ }^{1}$ Institute for Scintillation Materials, STC "Institute for Single Crystals", \\ National Academy of Sciences of Ukraine, \\ 60 Nauki Ave., 61001 Kharkiv, Ukraine \\ ${ }^{2}$ Institute for Single Crystals, STC "Institute for Single Crystals", \\ National Academy of Sciences of Ukraine, \\ 60 Nauki Ave., 61001 Kharkiv, Ukraine \\ ${ }^{3}$ V.Karazin Kharkiv National University, 4 Svobody Sq., \\ 61022 Kharkiv, Ukraine
}

Received December 22, 2015

\begin{abstract}
Interaction of $\mathrm{Zr}$ getter with oxygen-containing admixtures being most abundant in molten alkali metal iodides (deoxidization) is studied. Reaction of $\mathrm{Zr}$ with oxide ions (in form of the corresponding alkali metal oxide) is characterized by very negative enthalpy and Gibbs energy values that make the deoxidization process very favorable. Practically the interaction leads to decrease of $\mathrm{O}^{2-}$ concentration by a factor of ca. 6. Interaction of $\mathrm{Zr}$ with carbonate ions is shown both by the calculations and by experiment eщ lead to the formation of carbon particles (suspension) in the melts that causes certain limitations of the getter treatment for the purification of practically used growth iodide melts.
\end{abstract}

Keywords: cesium iodide, melt, deoxidization, zirconium.

Исследовано взаимодействие металлического циркония (геттер) с наиболее распространенными кислородсодержащими примесями (раскисление) в расплавленных йодидах щелочных металлов. Реакция циркония с оксид-ионами (в форме соответствующего оксида щелочного металла) характеризуется отрицательными значениями энтальпии и свободной энергии Гиббса, что свидетельствует о термодинамической выгодности процесса раскисления. Практически это взаимодействие приводит к снижению равновесной моляльности оксид-ионов в расплаве йодида цезия приблизительно в 6 раз. Экспериментально показано и подтверждено расчетом, что реакция циркония с карбонат-ионами приводит к образованию частиц углерода (суспензия), что налагает некоторые ограничения на применение геттеров для раскисления практически используемых йодидных расплавов.

Особливості розкислення розтопу CsI цирконісвим геттером. Ю.М.Дацько, Т.П.Реброва, В.Л.Чергинець, В.О.Науменко, О.Л.Ребров, П.В.Матейченко, І.М.В’юник.

Досліджено взаємодію металічного цирконію (геттер) з найбільш поширеними оксигенвмісними домішками (розкислення) у розтоплених йодидах лужних металів. Реакція цирконію з оксид-іонами (у формі відповідного оксиду лужного металу) характеризується негативними значеннями ентальпії і вільної енергії Гібса, що свідчить про термодинамічну вигідність процесу розкислення. Практично ця взаємодія веде до зниження рівноважної моляльності оксид-іонів у розплаві йодиду цезію приблизно у 6 разів. Експериментально показано і підтверджено розрахунками, що реакція цирконію з карбонат-іонами веде до утворення частинок вуглецю (суспензія), що накладає деякі обмеження на застосування геттерів для розкислення йодидних розтопів, що використовуються на практиці. 


\section{Introduction}

Single crystals of undoped cesium iodide are widely used for precision measurements in high-energy physics [1, 2]. However, for this purpose the crystal should possess good performance and high radiation hardness. These properties are known to be essentially dependent on the technology of crystal obtaining (the growth procedure, purity of the raw). In particular, the presence of admixtures increases the fraction of the slow components in the scintillation pulse that makes the scintillator slower.

Oxygen-containing admixtures are the most abundant ones and their appearance in the growth melt and, hence, in the obtained crystals is caused by interactions of the initial CsI with traces of water, oxygen and carbon dioxide which are contained either in the atmosphere or in the salt (hygroscopic moisture, organic admixtures). It makes the treatment (deoxidization) of the melt to be the most important procedure immediately preceding the crystallization process (crystal growth).

The deoxidization of halide melts can be performed by two common ways: the treatment in the reactive gas atmosphere and the precipitating deoxidization.

The common drawback of treatment of iodide melts in reactive gas atmosphere consists in supply or formation in situ of very aggressive substances such as $\mathrm{HI}$ or $\mathrm{I}_{2}$, which cause intensive corrosion of metal parts of equipment. Because of this reason the use of gases for purification of iodide melts in manufacturing conditions seems undesirable.

In this relation the precipitating deoxidization recently proposed in our work [3] presents more available way of iodide melt purification since addition of deoxidizing dopants does not result in the formation of aggressive gases. The destruction of the most abundant oxygen-containing admixtures $\mathrm{OH}^{-}$and $\mathrm{CO}_{3}{ }^{2-}$ by action of cation acids:

$$
\begin{gathered}
\mathrm{Mg}^{2+}+2 \mathrm{OH}^{-} \rightarrow \mathrm{MgO} \downarrow+\mathrm{H}_{2} \mathrm{O} \uparrow \\
\mathrm{Mg}^{2+}+\mathrm{CO}_{3}^{2-} \rightarrow \mathrm{MgO} \downarrow+\mathrm{CO}_{2} \uparrow
\end{gathered}
$$

results only in formation of gases which are atmosphere components. It should be noted that the above mentioned admixtures (hydroxide and carbonate) are formed because of interaction of water and carbon dioxide with CsI raw or melt at the stages preceding the crystal growth:

$$
\begin{gathered}
2 \mathrm{H}_{2} \mathrm{O} \uparrow+2 \mathrm{I}^{-} \rightarrow 2 \mathrm{OH}^{-}+2 \mathrm{HI}, \\
\mathrm{CO}_{2} \uparrow+\frac{1}{2} \mathrm{O}_{2} \uparrow+2 \mathrm{I}^{-} \rightarrow \mathrm{CO}_{3}^{2-}+\mathrm{I}_{2} \uparrow .
\end{gathered}
$$

Therefore, the gases yielded as products of reactions (1) and (2) do not create additional contamination of the growth atmosphere.

The use of cation acids, nevertheless, has disadvantages connected with the existence in the melt of the cation-scavenger and the product of its interaction with oxygen containing admixtures. The first, since the addition of the dopant should be equal to the total concentration of the admixtures and the excess of the scavenger should worsen the quality of the grown Csl crystal. The second, the formed metal oxide stays in contact with the iodide melt and can be partially dissolved. Therefore, only cations forming oxides with extremely low solubilities in melts $\left(\mathrm{Mg}^{2+}, \mathrm{Y}^{3+}\right)$ can be recommended for the purification [3].

The Red-Ox variation of the precipitating deoxidization consisting in the treatment of purified melt by a metal-getter [4] is free from the former drawback proper to cations-scavengers: the refractory metal itself is insoluble in the melt and cannot contaminate the melt and crystals. The Red-Ox variation was checked on $\mathrm{Zr}$-Csl (Aldrich, $5 \mathrm{~N})$ system and the high efficiency of $\mathrm{Zr}$ getter was confirmed.

Nevertheless, some questions connected with this way of the purification remain. Taking into account very high reducing properties of $\mathrm{Zr}$ it can be assumed that gases yielding due to decomposition of the main oxygen-containing admixtures may react with the remaining metal with formation of gaseous hydrogen (from $\mathrm{H}_{2} \mathrm{O}$ ) and solid carbon (from $\mathrm{CO}_{2}$ ) and the presence of the latter product is especially undesirable.

The purpose of the present work consists in investigation of interaction of $\mathrm{Zr}$ with Csl melt prepared from the raw with higher level of contamination by oxygen-containing admixtures than CsI Aldrich, 5N.

\section{Experimental}

Cesium iodide of two kinds of quality was used in the studies of deoxidization process and the crystal growth: CsI supplied by Aldrich with the mass fraction of the main substance of 0.99999 (kept for a year) 
Table. Thermodynamic parameters of interactions between some oxoderivatives of alkali metals with zirconium at $1000 \mathrm{~K}$

\begin{tabular}{|c|c|c|c|c|c|}
\hline & No. & Reaction & $\begin{array}{c}\text { Type of } \\
\text { calculation }\end{array}$ & $\Delta H, \mathrm{~kJ} \cdot \mathrm{mol}^{-1}$ & $\Delta G, \mathrm{~kJ} \cdot \mathrm{mol}^{-1}$ \\
\hline SM & $\beta W 6231$ & WNa32@23VuO4 +3RAp+4 3EOIZr4 & $3 G \Phi^{2}$ Ulich & अव2 $6 \mathrm{Fa}^{\mathrm{M}} \mathrm{Na}$ & -341.6 \\
\hline $\mathrm{rO}_{2} B$ & ८ЙॅW & $223 W \partial \mathrm{K} 323 и O 4 O 4+43 * O Z r 43 \Phi L 43 н$ & $\left.W 432{ }^{2}{ }^{\mathrm{l}} 4 \Phi \mathrm{Lich}+43\right)$ & ) $W 43 \mathrm{~d} 43.8$ & -458.4 \\
\hline $\mathrm{O}_{2} 5$ & $\pi 322$ & $23 W \quad 2 @ 22 @ 2343 R A+43\} O Z r 43 ? \Phi L 43 W 4$ & s $p$ Cs4 $4^{\text {nd }}$ Ulich $4 A+$ & $++4 \quad 3-4930 \mathrm{ZZ}$ & -471.3 \\
\hline $23 S$ & 292 & $23 R ! C O 3 ! \mathrm{CO} \quad 3 s 433 R A+43-O Z r 43 \Phi L 43-O Z r$ & 2@2compate43_R & $R A @+43390.82 @ 2 \beta$ & $\phi(43 \backslash R A 3+3458 C B$ \\
\hline
\end{tabular}

and the reagent of "extra pure" quality produced by Technoprom, Saki (kept for 2 years). The different term of the storage should provide different degree of contamination by oxygen-containing admixtures because of process (4). Concentrations of carbonate ion in the said chemicals (raw) were ca. $5 \cdot 10^{-4} \mathrm{~mol} \cdot \mathrm{kg}^{-1}$ (Aldrich) and ca. 1.5 $10^{-3} \mathrm{~mol} \cdot \mathrm{kg}^{-1}$ (Technoprom).

$\mathrm{Zr}$ shavings were obtained from the metal of $4 \mathrm{~N}$ purity. Before the experiment they were treated by diluted $\mathrm{HCl}(4 \mathrm{~N})$ to remove the traces of other metals which may remain on the surface after mechanical treatment. In the potentiometric experiments we used amounts of Zr providing surface area $c a .0 .5 \mathrm{~cm}^{2}$.

The study consisted of the following experiments:

- a weight of the metal shaving was added to molten $\mathrm{Csl}$ heated to $973 \mathrm{~K}$, and the decrease of oxide ion concentration in the melt was detected by a potentiometric method with the use of an electrode reversible to oxide ion;

- commercial Csl salt and the metal shaving was placed in a growth ampoule which then was heated to $973 \mathrm{~K}$. The melt with the metal pieces was kept under vacuum for a day; after that a single crystal was grown from the melt by the Bridgman method.

- the surface of the getter after crystal growth or deoxidization process was studied by SEM.

For studying the processes of "getter-melt" interaction in situ we used the potentiometric cell with a membrane oxygen electrode $\mathrm{Pt}\left(\mathrm{O}_{2}\right) \mid \mathrm{YSZ}$ (where $\mathrm{YSZ}$ the $0.9 \mathrm{ZrO}_{2}-0.1 \mathrm{Y}_{2} \mathrm{O}_{3}$ ceramics):

$$
\mathrm{Ag} \mathrm{Ag}^{+}(0.1 \mathrm{M}), \mathrm{Csl}:: \mathrm{Csl}, \mathrm{O}^{2-}|\mathrm{YSZ}|\left(\mathrm{PtO}_{2}\right) \text {. }
$$

The presented potentiometric cell was first calibrated with known weights of $\mathrm{KOH}$ serving as a donor of oxide ions since its dissociation in molten salts:

$$
2 \mathrm{OH}^{-} \rightarrow \mathrm{H}_{2} \mathrm{O} \uparrow+\mathrm{O}^{2-}
$$

occurred completely in dry inert atmosphere. This gave us possibility to obtain the dependence of emf of cell (4) on pO ( $p \equiv-\log m_{\mathrm{O}}{ }^{2-}$, where $m_{\mathrm{O}}{ }^{2-}$ the equilibrium molality of oxide ions in Csl melt). The plot was further used for recalculation of the emf values obtained at the deoxidization process into $m_{\mathrm{O}}{ }^{2-}$ and $\mathrm{pO}$.

Microphotographs were made using JSM $6390 \mathrm{LV}$ scanning electron microscope with a $\mathrm{MAX}^{\mathrm{N}} \mathrm{X}$-ray microanalysis system.

\section{Results and discussion}

\section{Thermodynamic predictions}

As is known, zirconium possesses considerable affinity to oxygen and the heat of formation of $\mathrm{ZrO}_{2}$ is $\mathrm{ca}$. $550 \mathrm{~kJ} \cdot \mathrm{mol}^{-1}$ per 1 oxygen [5]. Therefore, at high temperatures it is able to displace even the most active alkali metals from their oxocompounds. Thermodynamic analysis performed using existing data on sodium and potassium compounds ( $2^{\text {nd }}$ Ulich approximation, $\Delta c_{p}=$ const) [5] permit to construct the scheme of interactions in molten salts which can give an imagination about processes taking place during halide melt deoxidization (see Table). Temperature $1000 \mathrm{~K}$ was chosen since melting of alkali metal iodides occurs in the vicinity of the said temperature.

As seen from this Table, all the processes with participation of oxocompounds and metallic zirconium are characterized by very negative free Gibbs energies. This means 
that the equilibrium state of all listed processes should be shifted to the right side.

Comparison of thermodynamic parameters for reactions of $\mathrm{Na}_{2} \mathrm{O}, \mathrm{K}_{2} \mathrm{O}$ and $\mathrm{Cs}_{2} \mathrm{O}$ with metallic zirconium gives possibility to state that the difference between standard enthalpies of their formation is the main part of difference in $\Delta G$ or $\Delta H$ of the said reactions. The thermodynamic favorability of these process increases going from $\mathrm{Na}_{2} \mathrm{O}$ to $\mathrm{Cs}_{2} \mathrm{O}$ and it means that purification with getters is the most effective in the case of cesium halides.

These speculations are referred to partial pressure of 1 atm and naturally, that under vacuum volatile alkali metal will be evaporated from the melt providing completeness of the corresponding chemical reactions. For example, reaction:

$$
2 \mathrm{Na}_{2} \mathrm{O}+\mathrm{Zr} \rightleftarrows 2 \mathrm{Na}_{2, \text { gas }}+\mathrm{ZrO}_{2}
$$

is characterized by $\Delta G=-293.4 \mathrm{~kJ} \cdot \mathrm{mol}^{-1}$ at $1000 \mathrm{~K}$.

As to reaction of $\mathrm{CO}_{2}$ or carbonate ions with $\mathrm{Zr}$, it should to note that these compounds will be decomposed completely. Nevertheless, a question arises, what amount of the oxygen-containing admixtures (existing, mainly, as carbonates) will affect the quality of the grown single crystals due to the decomposition with formation of carbon.

Interaction of $\mathrm{Zr}$ with oxygen-containing admixtures in molten CsI

The addition of $\mathrm{Zr}$ to $\mathrm{Csl}$ (Aldrich) placed in the potentiometric cell causes the sequential rise of pO (Fig. 1, curve 1) that means decrease of oxide ion concentration in the

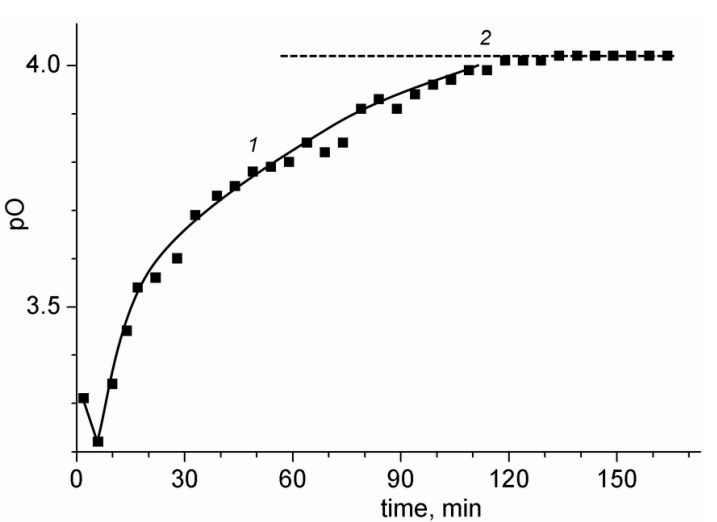

Fig. 1. The dependence of pO vs. time for process of deoxidization of Csl melt by zirconium getter at $973 \mathrm{~K}: 1$ - the section where the purification occurs, 2 - the plateau section.

melt up to a certain point where a plateau begins (Fig. 1, line 2). The plateau section corresponds to moment when the surface of zirconium is completely covered by interaction products that stops the following running of the deoxidization process.

Knowing the initial and final concentration of oxide-ion before (the starting pO value) and after purification ( $\mathrm{pO}$ value at the plateau) and the square of surface of the shaving permits to estimate the surface capacity of the used $\mathrm{Zr}$ getter with respect to oxygen as $0.42 \mathrm{~mol} \cdot \mathrm{m}^{-2}$ [6]. The concentration of oxide ion during the purification process is decreased by a factor of 6 , i.e., the deoxidizing action of the getter on Csl melt is effective enough and the time of the treatment should be not less than $2 \mathrm{~h}$.

The initial stage can be considered as an irreversible process, therefore, its running
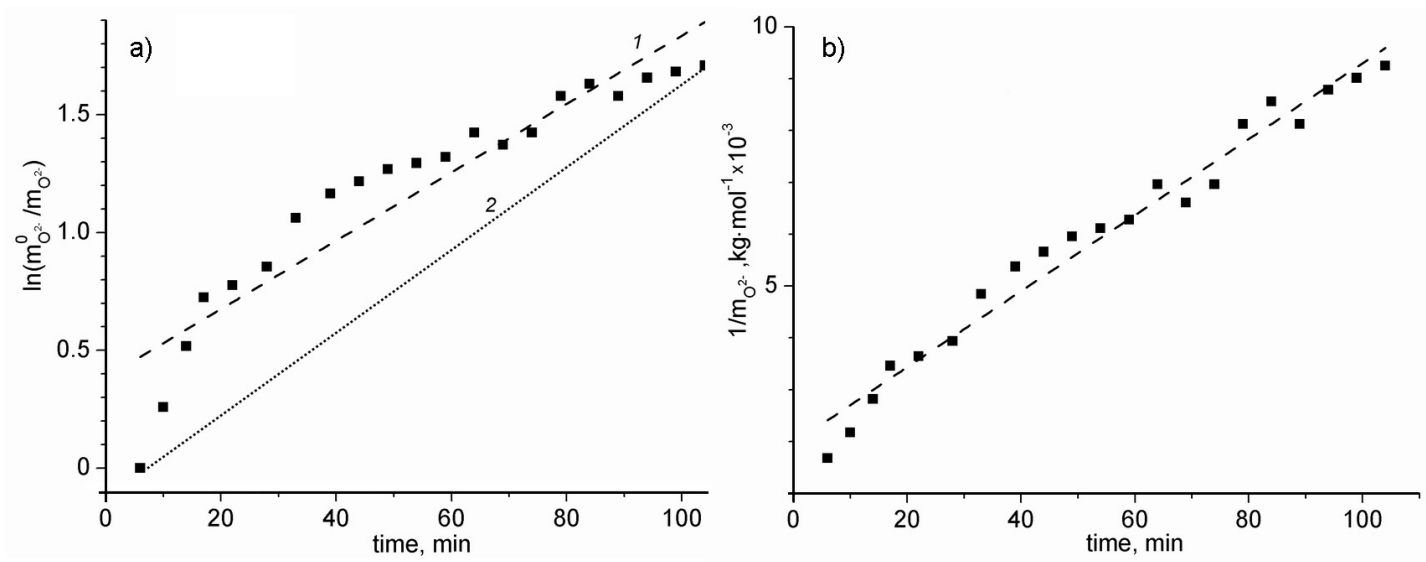

Fig. 2. The dependences of oxide ion concentration vs. time for process of deoxidization of Csl melt by zirconium getter at $973 \mathrm{~K}$ made for determination of kinetic parameters: a $-1^{\text {st }}$ order dependence, $\ln m_{\mathrm{O}}{ }^{2-}=f(t), 1-$ approximation by least squares method; $\mathrm{b}-2^{\text {nd }}$ order dependence, $1 / m_{\mathrm{O}}{ }^{2-}=f(t)$. 


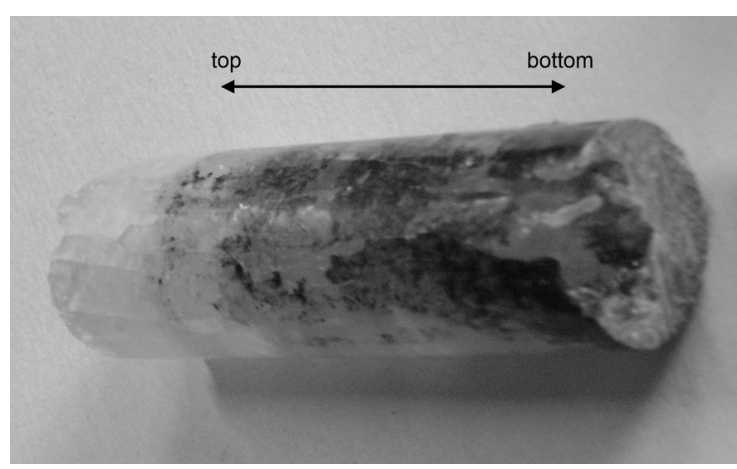

Fig. 3. Photo of Csl single crystals grown from the melt contaminated with carbonate ion.

should be subjected to the known kinetic regularities. Since we can determine current concentration of only oxide ion the running of the process can be described by pseudoorder, i.e., power in which oxide ion concentration enters in the kinetic equation of the following general form:

$$
w=k \cdot m_{O^{2-}}
$$

where $k$ the rate constants of the purification process.

The necessary data for the estimation of the process kinetics are presented in Fig. 2 . It should be noted that, although the dependence of $\ln m_{\mathrm{O}}{ }^{2-}$ against time (proper to reactions of the $1^{\text {st }}$ order) can be considered as practically linear (approximation line 1 , $r_{x y}=0.931$ at 19 degrees of freedom) one can see that actually this dependence is somewhat convex to ordinate axis that is obvious if we consider position of the experimental points comparing with line 2 (Fig. 2a). The similar behavior is observed to "pO - time" dependence (Fig. 1) which is similar to the discussed logarithmic one (Fig. 2a).

Contrary, the dependence of $1 / \mathrm{m}_{\mathrm{O}}{ }^{2-}$ vs. time is linear with small oscillations of the experimental parameters near the approximation line $\left(r_{x y}=0.985\right.$ at 19 degrees of freedom) (Fig. 2b). These speculations help us to determine the pseudo-order of interaction " $\mathrm{Zr}$ - oxygen admixtures" as second, and the slope, $73.3 \pm 7 \mathrm{~kg} \cdot \mathrm{mol}^{-1} \cdot \mathrm{mol}^{-1}$ is the rate constant of this process. The obtained result corresponds completely to stoichiometry of reaction (8) that leads to formation of $\mathrm{ZrO}_{2}$. On the other hand such value of pseudo-order can confirm that reaction (8) is the limiting stage of the process whereas the reduction of $\mathrm{CO}_{2}$ to carbon can not be detected by potentiometric method since this reaction is not accompanied with

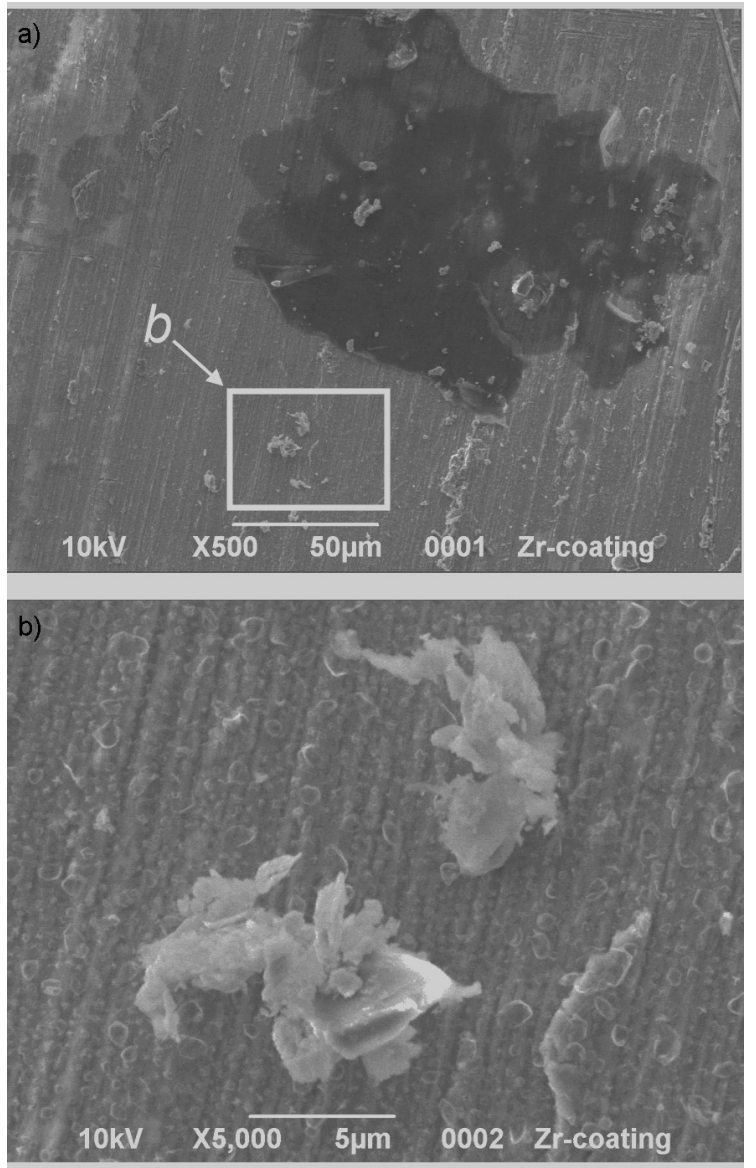

Fig. 4. SEM photographs of surface of $\mathrm{Zr}$ shaving used for deoxidization of Csl melt: $\mathrm{a}-$ carbon particle, $\mathrm{b}-\mathrm{ZrO}_{2}$ particles.

formation or fixation of oxide ions in molten Csl.

For treatment of Csl (Technoprom) with $\mathrm{Zr}$ pO changes were insignificant because of very high concentration of carbonate and they did not permit to make quantitative estimations.

Detection of products of " $\mathrm{Zr}$ - oxygen admixtures" interaction

To state what products are formed as a result of destruction of oxygen-containing admixtures by the metal getter, we performed the growth of Csl single crystals in quartz ampoules with addition of $\mathrm{Zr}$ shaving to the initial melt. In the case of Aldrich raw the crystal remained completely transparent and possessed scintillation parameters which were described elsewhere [4].

The result of treatment of more contaminated with carbonate Saki raw (which was kept for more long time) deserves special figure (Fig. 3). 
As is seen, the bottom part of the grown single crystals contains appreciable amount of black inclusions (suspension) which is displaced to the ampoule walls during the growth process. Analysis showed that this is carbon soot containing $\mathrm{ZrO}_{2}$. It means, that zirconium getter can be used for additional deep purification of "fresh" iodide raw of high purity, however, it is not usable for the purification of melts prepared from the raw appreciably contaminated by carboncontaining admixtures (carbonates, organic salts) because of destruction of the latter with the formation of suspended carbon.

To get more information about the deoxidization process we obtained SEM photo of the zirconium surface after the interaction (Fig. 4).

The surface on the shaving is covered by particles of $\mathrm{ZrO}_{2}$ (Fig. 4a) and carbon (Fig. $4 \mathrm{~b}$ ), and the quantitative analysis of the sample of shaving gives the following ratio: $\mathrm{Zr}-24.0$ at. $\%, \mathrm{O}-45.2$ at. $\%$ and $\mathrm{C}-30.1$ at.\%, i.e. there is $\mathrm{ZrO}_{2}$ and $\mathrm{C}$ as the main interaction products. Ditto, there is a definite amount of sodium on the $\mathrm{Zr}$ surface, ca. 0.51 at. $\%$. Simply it means that the formed $\mathrm{ZrO}_{2}$ serves as additional sorbent for sodium and the chemisorption process takes place according to the following equation:

$$
2 \mathrm{Na}^{+}+\mathrm{O}^{2-}+\mathrm{ZrO}_{2} \downarrow \rightleftarrows \mathrm{Na}_{2} \mathrm{ZrO}_{3} \downarrow
$$

leading to the formation of sodium zirconate which is insoluble in molten alkali metal halides (excluding lithium salts because of their strong affinity to oxide ion [7]). This reaction also gives the evidence of effective usage of dispersed $\mathrm{ZrO}_{2}$ (powder) for removal of sodium admixtures from molten cesium halides.

\section{Conclusions}

Processes of interaction of $\mathrm{Zr}$ with the most abundant oxygen-containing admix- tures (alkali metal oxides and carbonates) were demonstrated by thermodynamic analysis to possess very negative Gibbs energy values that makes the said deoxidization process very favorable. Practically the interaction leads to decrease of $\mathrm{O}^{2-}$ concentration by a factor of ca. 6 .

The reaction running is described by kinetic equation of the second pseudo-order. The rate constant of the deoxidization process and the surface capacity of zirconium with respect to oxygen in molten Csl are determined.

Interaction of zirconium with carbonate ions is shown both by the calculations and by experiment to lead to the formation of carbon particles (suspension) in the melts that causes certain limitations on use of getters for the purification of practical growth iodide melts. $\mathrm{ZrO}_{2}$ formed as one of the deoxidization process products shows acidic properties and fixes sodium probably, in the form of $\mathrm{Na}_{2} \mathrm{O}$ to insoluble sodium zirconate.

Acknowledgement. This work was supported by National Academy of Sciences of Ukraine, project of young scientists No A52-15 (St. Reg. No. 0115U004422).

\section{References}

1. J.Brose, Nucl.Instr. Meth. Phys. Res., A, 379, 495 (1996).

2. M.Doroshenko, K.Abe, J.K.Ahn et al., Nucl. Instr. Meth. Phys. Res., A, 545, 278 (2005).

3. V.L.Cherginets, T.P.Rebrova, Yu.N.Datsko et al., Mater. Lett., 65, 2416 (2011).

4. V.L.Cherginets, T.P.Rebrova, Yu.N.Datsko et al., J.Cryst. Growth, 380, 143 (2013).

5. http://www.update.uu.se/ jolkkonen/pdf/C RC TD.pdf

6. T.P.Rebrova, V.L.Cherginets, Yu.N.Datsko et al., Patent of Ukraine 102492 (2013).

7. V.L.Cherginets, O.V.Demirskaya, T.P.Rebrova, J.Chem.Thermodynam., 36, 115 (2004). 